Research, part of a Special Feature on Scaling and Governance

\title{
Disentangling Scale Approaches in Governance Research: Comparing Monocentric, Multilevel, and Adaptive Governance
}

\author{
Catrien J.A.M. Termeer $^{1}, \underline{\text { Art Dewulf }}^{1}$, and $\underline{\text { Maartje van Lieshout }}^{1}$
}

\begin{abstract}
The question of how to govern the multiscale problems in today's network society is an important topic in the fields of public administration, political sciences, and environmental sciences. How scales are defined, studied, and dealt with varies substantially within and across these fields. This paper aims to reduce the existing conceptual confusion regarding scales by disentangling three representative approaches that address both governance and scaling: monocentric governance, multilevel governance, and adaptive governance. It does so by analyzing the differences in (1) underlying views on governing, (2) assumptions about scales, (3) dominant problem definitions regarding scales, and (4) preferred responses for dealing with multiple scales. Finally, this paper identifies research opportunities within and across these approaches.
\end{abstract}

Key Words: adaptive governance; levels; monocentric governance; multilevel governance; scale mismatch; scaling

\section{INTRODUCTION}

During the last decades it has become common in the fields of public administration, political sciences, and environmental sciences to stress the multilevel and multiscale character of today's problems and today's politics. Although scale is not a new subject, its importance has grown over the last years, and it plays a key role in crossdisciplinary research on the governance of socialecological systems. This can be explained by the increasing concerns for sustainability issues in the context of a globalizing world. Problems like climate change, droughts and floods, pollution, and threats to biodiversity cut across traditional jurisdictions and scopes of organizations, and stretch across local to global scale levels (Dietz et al. 2003). Environmental scientists have developed a growing interest in governance issues and have started interdisciplinary programs that include scales as important research topics (Young 2002, Biermann 2007, Folke et al. 2007, Young et al. 2008).

Because both the concepts of scale and governance are defined in a variety of ways, we start with some clarification. In this paper, we follow Gibson et al.'s (2000) broad definitions of scale and level because they are meant to be applicable across a range of disciplines. The authors define "scale" as the spatial, temporal, quantitative, or analytical dimensions used to measure and study any phenomenon, and "levels" as the units of analysis that are located at different positions on a scale. A number of different types of scales have been identified by Cash et al. (2006). Next to the classic spatial and temporal scales, they consider jurisdictional, institutional, networks, management, and knowledge scales to be important for policy studies. Often, levels on a scale are organized in a hierarchical fashion (Gibson et al. 2000) such that lower levels are part of more inclusive higher levels (e.g., the jurisdictional scale of state, province, and municipality, or the institutional scale of constitutions, laws, and operating rules). Also, regarding governance, we prefer the broader definition. While some authors reserve the governance definition for networks only (Rhodes 1997), we define governance as all modes of governing, whether they are developed and enforced by markets, hierarchies, or networks (Kjaer 2004). Hence, governing encompasses all 
those activities of social, political, and administrative actors that can be seen as purposeful efforts to guide, steer, control, or manage the pursuance of public goods (Kooiman 1993, Kjaer 2004).

Scale issues have a long history in ecology. In 1961, the political scientist Vincent Ostrom addressed the question of (jurisdictional) scales in his analysis of the polycentric political system of large metropolitan areas governed by a multiplicity of federal, state, city, and district level authorities. The starting point of his analysis is that public goods are not all of the same scale, and that scale not only implies the geographic domain but also the intensity or weight of the externalities (Ostrom et al. 1961: 833). For example, a dike to reduce the probability of flooding in a specific polder might benefit a larger area, but there are also opposite examples of shifting costs on to neighboring authorities. Governing problems arise when the scales of public goods do not correspond with the territorial boundaries of governmental authorities. This situation is complicated because at the same time there are "too many governments and not enough government" (Ostrom et al. 1961: 831). In the global environmental change literature, these issues have been studied using the concepts of fit, interplay, and scale. While horizontal interplay involves interactions occurring at the same level of social organization, vertical interplay is the result of interactions between different levels of social organization (Young 2002). In general, the lack of fit between the scale of resource governance systems and the scale of the resource systems that they are supposed to govern is the archetypical scale problem for environmental issues (Young 2002, Cash et al. 2006).

Traditionally, the spatial scale is the best studied scale (Cash et al. 2006) and provides the fundament for a discipline like geography. Closely related to the spatial scales are the jurisdictional scales, which are central in many governance studies. Due to longterm challenges in fields like climate change or food security, the temporal scale has been growing in importance too (Gibson et al. 2000). Externalities on temporal scales bring with them some specific governing problems because the future is surrounded by uncertainties and most politicians focus on showing results within their terms of office. This situation is, moreover, complicated by the rise of a network society and the assumed shift from monocentric, hierarchical, and well-institutionalized forms of government towards less formalized forms of governance in which state authority makes way for an appreciation of mutual interdependent stakeholders (Rhodes 1997, Pierre 2000, Blatter 2003, Kooiman 2003, Edelenbos 2005). To deal with these complexities, new approaches have arisen, such as polycentric governance, network governance, multilevel governance, earth system governance, and adaptive governance (Ostrom 1990, Kickert et al. 1997, Hooghe and Marks 2003, Folke et al. 2005, Biermann 2007).

Conceptual confusion arises because these approaches draw upon different definitions of, assumptions about, and preferred responses to, scale issues. Clarifying conceptual differences between approaches can facilitate clearer communication between different social and natural scientists who are engaged in researching governance of sustainability. This paper aims to reduce the existing conceptual confusion regarding scales by disentangling three representative approaches that address both governance and scaling: monocentric governance, multilevel governance, and adaptive governance. It does so by analyzing the differences in (1) underlying views on governing, (2) assumptions about scales, (3) dominant problem definitions regarding scales, and (4) preferred responses for dealing with multiple scales. Conceptual clarity could also provide insights into research opportunities within and across these approaches on dealing with scales in governing complex problems. Revealing some boundary research themes is the second aim of this paper.

In the next three sections, we present the results of our disentangling endeavor. We respectively discuss how the approaches of monocentric governance, multilevel governance, and adaptive governance deal with scale issues. In this overview, we are necessarily selective. Hence, the choice of literature reflects our interpretation. Then we compare the approaches and delineate key research themes. Finally, we formulate our conclusions regarding scale-sensitive governance to cope with complex sustainability issues.

\section{MONOCENTRIC GOVERNANCE: IN SEARCH OF THE IDEAL SCALE}

Monocentric governance refers to an approach in which the state is the center of political power and authority (Rhodes 1997, Pierre 2000, Kooiman 
2003). This center exerts control over society, economy, and resources. It does so by setting the agenda of societal problems and deciding upon policy goals and means, and by top-down implementation of its policies. Most new governance perspectives have been developed largely as a critique of this monocentric governance, also referred to as the government perspective (Rhodes 1997), hierarchical governance (Hill and Lynn 2004), command and control systems of governance (Kooiman 1993), or the classical modernist approach of governance (Hajer and Wagenaar 2003). In spite of these critiques, the monocentric approach still dominates many governance practices.

\section{Basic assumptions about scales}

The monocentric governance literature focuses mainly on the jurisdictional scales, "defined as clearly bounded and organized political units, e.g., towns, counties, states or provinces, and nations, with linkages between them created by constitutional and statutory means" (Cash et al. 2006). Ideally, a monocentric governance system consists of jurisdictions at a limited number of hierarchical government levels without overlaps in tasks (Huitema et al. 2009). According to this principle, most states have a three-level system, e.g., national government, provinces, and municipalities. Through hierarchical mechanisms, the power of the lower level governments is restricted by the higher level governments.

This body of literature makes extensive use of the scale concept. Here, the term "scale" refers mainly to the size of a jurisdiction and to the scope of its territory (Schaap 2005). Municipalities, for example, can differ in size from a few dozen to millions of inhabitants, and in scope from one to thousands of square kilometers. Generally, the number of citizens and square kilometers determine the incomes municipalities receive from national funds and local taxes. Consequently, they also determine the size of the governmental unit, including the number of employees. Large municipalities are those with a lot of inhabitants, a large geographical scope, and many civil servants. Monocentric governance literature pays much attention to the capacity of the government to steer and control society (Pierre 2000), and to its democratic legitimacy. A general assumption is that scale (meaning size) matters to guarantee a good governance capacity and citizens' representation (Dahl and Tufte 1973). There is a trade-off involved here: while a small municipality will not have the capacity to deal with complex environmental permits, a big municipality could run the risk of losing political trust among its citizens.

\section{Problem definitions in the monocentric governance approach}

According to the monocentric governance approach, problems will occur (1) when the scale of government bodies is either too big or too small, (2) when gaps exist in the layered government system, or (3) when responsibilities of government bodies conflict due to overlapping jurisdictions.

The first problem can be characterized as the search for the appropriate scale (meaning size) of government (Boyne 1995, Loughlin and Peters 1997). Many governmental units, especially municipalities, are considered to be too small to develop governance capacity to address current societal problems and deliver modern services. Arguments of economies of scale dominate this problem frame. "Bigger is cheaper", and larger units might provide more capacity and more room for employing specialized civil servants to cope with the growing complexity of societal problems (McKay 2004, Dollery et al. 2007). However, governmental units can also be qualified as too large. Organization size has an optimum (Staley 1992, Dollery et al. 2007). Above all, smaller units might increase the frequency of face-to-face contacts between politicians and citizens, and in that way enhance political trust (Kraaykamp et al. 2001, Denters 2002, Goldsmith and Rose 2002).

A second issue relates to tensions between the dynamics of social problems and the rigidity of the constitutionally rooted layered governmental systems. For example, the current governance systems are the product of times in which the climate issue was hardly of any importance. The Dutch Randstad region, with most of its gross added value below sea level, is very vulnerable to the impacts of climate change. This region consists of four provinces, four big municipalities (including Amsterdam and Rotterdam), and many smaller villages. Accordingly, the people in this metropolitan region have no common government to deal with the climate adaptation problems they share. Also, centralization or decentralization 
processes can cause tensions between the dynamics of social problems and the rigidity of the constitutionally rooted layered governmental systems. For example, the European Union increasingly views the region as the appropriate level at which to implement parts of the common agricultural and rural policy. However, most regions do not fit within geographical boundaries of municipalities, provinces, or states. These issues have also been termed the regional gap or the institutional void (Hajer and Wagenaar 2003).

Finally, we address the problems of overlapping jurisdictions. In the monocentric governance approach, much emphasis is given to the necessity of having clear distinctions between the levels of government and to a clear division of tasks and responsibilities. These distinctions are preferably constitutional or at least legally based, and authorities should be as exclusive as possible (Schaap 2005). Problems arise when these conditions are not met. The Dutch Randstad region, for example, is a legal non-entity (Ostrom et al. 1961). To cope with shared problems like climate change, many initiatives for better integration and cooperation between units are being developed. However, according the monocentric perspective, these initiatives are deemed problematic due to blurring boundaries between jurisdictions, overlapping authorities, duplicating functions, and conflicting responsibilities.

\section{Dominant responses}

Proponents of the monocentric governance perspective prefer to find responses to the above mentioned problems in a further clarification of responsibilities or in a structural change of the layered system. Informal arrangements of regional cooperation are rejected because they would obscure the separate responsibilities of each autonomous municipality or province (Loughlin and Peters 1997, Schaap 2005). Consequently, they do not consider cross-level interactions or integrations. If the geographical scope of a governmental unit is too small compared to the scale of the societal problems at stake, or if the size of the unit does not meet an economic/democratic optimum, amalgamation or even the creation of a new level of government is preferred (Schaap 2005).

Amalgamation, or merging authorities into larger units, is a gradually ongoing process in most countries. In the Netherlands, almost every year the number of municipalities has decreased, from 1016 in 1945 to 430 in 2010 . In spite of high expectations, amalgamations, as many evaluation studies show, do not deliver what they are supposed to (Bish 2001). Besides some improvements in capacity, e.g., more specialized employees and advanced Information and Communication Technology systems, the efficiency in terms of cost reduction does not increase, while the possibilities for citizen involvement and democratic legitimacy seem to decrease (Denters 2002, Larsen 2002, McKay 2004, Schaap 2005).

Structural reforms can also consist of abolishing existing governmental layers or developing new ones (Loughlin and Peters 1997). A remarkable number of such governmental reforms have been proposed and rejected over the last decade in Western Europe (Schaap 2005). In the Netherlands, for example, several attempts to set up a regional Randstad authority failed due to its threat to existing power relations, perceived lack of democratic legitimacy, and never-ending discussions about the preferred territorial scope. The structural reforms in Denmark can be considered as an exception. This reform, in operation since January 2007, reduced 275 municipalities to 98 and abolished 14 counties as the functions of the counties were transferred to the enlarged municipalities (Andersen 2008). Although this reform was aimed at strengthening local authorities in regional politics, results until now have shown that the central government is gaining a more influential position (Andersen 2008).

The monocentric governance approach is dominated by a search for the ideal scale and a belief that structural change can improve governmental capacity. However, the effects in practice prove to be disappointing. Next to this, changing governmental structures might be fruitful for some problems but will always lead to new boundary problems and new institutional mismatches. After all, public goods have different and changing scales.

\section{MULTILEVEL GOVERNANCE: DEALING WITH SCALE INTERDEPENDENCIES}

While the monocentric governance literature focuses mainly on the national domain, multilevel governance begins from the premise that policy and administration increasingly occur in international 
contexts. On the one hand, international organizations, like the European Union and the World Trade Organization, influence national governments. On the other hand, "domestic" actors more often play an active role in international policy processes and organizations (Marks 1993, Pierre 2000, Hooghe and Marks 2003). In addition, the multilevel concept has been related to the more general governance literature (Kooiman 1993, Rhodes 1997). Accordingly, multilevel governance emphasizes the threefold displacement of state power and control: (1) upwards to international actors and organizations, (2) downwards to regions, cities, and communities, and (3) outwards to civil society and non-state actors (Pierre and Peters 2000). Governing is then interpreted as a process of continuous interactions among governments and private entities, operating at, and between, several administrative levels and ultimately aiming at the realization of collective goals.

\section{Basic assumptions about scales}

As the term "multilevel governance" implies, the concept of levels is central. The term refers to different levels (supranational, national, regional, and local) on the jurisdictional and/or (corresponding) spatial scales (Van Kersbergen and Van Waarden 2004). The underlying normative assumption is that dispersion of governance across multiple jurisdictions is both more efficient and normatively superior to central state government: "governance must operate at multiple scales in order to capture variations in the territorial reach of policy externalities" (Marks and Hooghe 2004: 16). This assumption is based on the hypothesis that it is impossible to find fixed matches between levels on the administrative and ecological scales. Climate problems, for example, have both local and global causes and effects, and thus need to be addressed in interplay between local and global authorities. Multilevel governance, with its focus on activating relevant cross-level interactions, is considered to have more potential to deal with complex multiscale problems.

Because there is no convergence on how these multilevel governance should be organized, Marks and Hooghe (2004) have distinguished two types of multilevel governance. The first type conceives of a limited number of general purpose jurisdictions. They bundle together multiple functions, including a range of policy responsibilities, and there is only one relevant jurisdiction at a particular spatial scale, such as a municipality or a European Union. This vision resembles aspects of monocentric governance but differs in its focus on cross-level interactions. Climate adaptation measures such as water storage capacity and flood resilient infrastructures have to be developed and implemented in a variety of policy sectors on different levels of government. This calls for coordination between these levels. The second type conceives of a great number of specialized jurisdictions that fulfill distinct functions, for example, solving a common pool resource problem or adjudicating international climate disputes. In this vision, there is a wide range of public and private actors who operate at diverse jurisdictional levels and collaborate in shifting arrangements: "they come and go as demands for governance change" (Hooghe and Marks 2003: 241). These jurisdictions are lean, flexible, and functional and will partly overlap. Examples vary from international round tables on sustainable palm oil to the Dutch water boards, whose main tasks are to construct and maintain dikes so as to reduce the probability of flooding in their polder.

\section{Problem definitions}

The multilevel approach offers many insights on how to deal with complex multiscale and multisector issues, but it also identifies some key concerns and problems that arise in the multilevel governance world. The first concern refers to coordination dilemma and perceived ineffectiveness. While the chief benefit of multilevel governance lies in its scale flexibility, its chief cost lies in the transaction costs of coordinating multiple actors at multiple levels (Scharpf 1997, Hooghe and Marks 2003). The involvement of many government, business, and civil society actors is often referred to in a negative sense in terms of administrative fuss, fragmentation, or meaningless compromises. Especially regarding urgent matters such as food safety crises, some plead for a reduction of complexity to accelerate decision-making processes. Some scholars argue that large-scale changes, such as climate change, are difficult to govern via multilevel approaches and networks (Duit and Galaz 2008).

The second group of problems refers to concerns regarding the dispersion of central government authority. Rhodes (1997) argues that the shift in authority results in a "hollowed out" state, and 
Jordan (2001) stresses that policy bargaining encompasses multiple levels but lacks democratic control. Furthermore, multilevel governance can result in a lack of transparency and democratic legitimacy. Many of the emerging networks in the European arena are opened up to include different layers of government as well as actors from market and civil society, but they lie outside the control of traditional member state executives (Van Tatenhove 2003).

\section{Dominant responses}

Following the multilevel governance approach, the solution for inefficiency is not sought in amalgamations or in creating new layers of government (Schaap 2005). Changing the multilevel structure itself can be seen as an example of what Ostrom refers to as a panacea approach to matching governance systems with problems in the social-ecological system (Ostrom et al. 2007). Responses reflect the two visions of multilevel governance mentioned above.

Type 1 multilevel governance limits coordination costs by constraining the number of jurisdictions involved, by designing coordination procedures, and by imposing a shadow of hierarchy across them (Hooghe and Marks 2003). An example is the Dutch program "Room for the River", which is aimed at developing river-widening measures to improve both the safety of the local inhabitants and the spatial quality of the river areas. The three ministries involved decided to actively involve regional and local government agencies, nongovernmental organizations, and inhabitants. Through the introduction of several interfaces between scales and levels they reduced the coordination costs and accelerated the decision-making process (Ten Heuvelhof et al. 2007). The ministries asked the Dutch provinces and municipalities to issue regional advice on a package of policy measures that met the objectives set by the national government and which could be combined with other (more local) policy objectives. If the regional actors did not arrive at a shared advice within a strict time schedule, the central government would take over the responsibilities. Through this deadline, they imposed "a shadow of hierarchy" (Scharpf 1997).

Type 2 multilevel governance offers an alternative solution. It sets no limits on the number of jurisdictions but aims at minimizing the negative externalities and spillover between jurisdictions. Hypothetically, in the case of the Room for the River program, this could have led to an alternative solution, like developing a temporary riverine authority. Ostrom's work presents many devices and principles on how to design multilevel arrangements (Ostrom 1990, Dietz et al. 2003).

The nature of multilevel governance is that it will conflict with existing norms of democratic legitimacy because it will always go beyond the control of elected politicians or state executives. In spite of this, many solutions are found in attempts to regain a grip on these processes. Sørensen and Torfing (2005) revealed the emergence of new postliberal theories of democracy. These theories perceive the blurring of the borderlines between nation states and between the public and the private no longer as a threat to democracy but as a prerequisite for the democratic regulation of processes of policy making in complex multilayered societies (Sørensen and Torfing 2005).

\section{ADAPTIVE GOVERNANCE: MATCHING SCALES AND LINKING LEVELS}

Adaptive management (Holling 1978, Berkes and Folke 1998, Gunderson 1999) has been put forward as an integrated, multidisciplinary approach for confronting complexity and uncertainty in natural resources issues. It acknowledges that managed resources will change as a result of human intervention, that surprises are inevitable, and that new uncertainties will emerge. Adaptive management can be defined as "a systematic process for improving management policies and practices by learning from the outcomes of management strategies that have already been implemented" (Pahl-Wostl et al. 2007: 4). Originally developed as a management approach for ecological systems, adaptive management has evolved into an interdisciplinary field of research and action, also known under the broader term of adaptive governance (Folke et al. 2005). This field has the ambitious goal of developing new governance concepts that can handle the inherent complexity and unpredictability of dynamic social-ecological systems. Adaptive governance assumes a world that is characterized by both continuous and abrupt changes, often with largely unpredictable consequences. Vulnerable ecosystems, for example, can rapidly shift into undesired states and stop providing ecosystem services (like food or scenery) 
to society. Systems show high adaptability when the actors have the capacity to reorganize the system within desired states in response to changing conditions and disturbance events (Folke et al. 2005: 444). Adaptive governance takes the challenge of really accepting uncertainty by being prepared for change and surprise and by enhancing the adaptive capacity to deal with disturbance (Folke et al. 2005: 464).

\section{Basic assumptions about scales}

The linkages between social and ecological systems are of key importance in the adaptive governance approach. Multiple scales and levels are central to these linkages. In contrast to monocentric and multilevel governance approaches, the concept of scales is not limited to spatial and jurisdictional scales only. Temporal, institutional, management, network, and knowledge scales are also considered (Cash et al. 2006, Gupta 2008).

Multilevel refers to the presence of more than one level, and multiscale refers to the presence of more than one scale, but more significant from an adaptive governance perspective are the cross-level and cross-scale interactions. Cross-level interaction refers to the interactions among levels within a scale. Institutional cross-level interactions, for example, occur when there is vertical interplay between regimes located at higher and lower levels of social organization (Young 2006). Cross-scale refers to interactions across different scales, for example, between ecological and jurisdictional scales. Furthermore, these cross-level and cross-scale interactions can change in strength and direction over time, adding to the complexity of socialecological systems.

\section{Problem definitions}

Accordingly, scale issues in the adaptive governance literature can be divided roughly into two categories: cross-scale issues and cross-level issues. Cross-scale issues are the result of the existence of multiple relevant scales and the crossscale interactions between them. The archetypical cross-scale issue is the mismatch between the scale of social organization and the biogeophysical scale of resources in time and/or space (Young 2002, Olsson et al. 2007). Typically, resources like water, biodiversity, or climate do not stop at the borders of communities, regions, or countries. But other types of mismatches between scales are identified as well, e.g., between the scale at which knowledge is produced (e.g., global climate models) and the scale at which decisions have to be made (e.g., local adaptation decisions). Scale mismatches have been defined as situations where the scale of environmental variation and the scale of the social organization responsible for management are aligned in such a way that one or more functions of the social-ecological system are disrupted (Cumming et al. 2006). This can take three different forms: (1) spatial mismatches will occur when the spatial scales of management and the spatial scales of ecosystem processes do not align appropriately, (2) temporal mismatches will occur when the temporal scales of management and the temporal scales of ecosystem processes do not align appropriately, e.g., when slow bureaucratic processes are unable to react to rapid ecological changes, and (3) functional mismatches will occur when the functional scales of management do not align appropriately with the functional scales of ecosystem processes, e.g., when a city grows beyond the ability of the ecosystem to provide it with fresh water.

Cross-level issues are the result of cross-level interactions between multiple levels on a scale. Depending on the scale at hand, cross-level issues can take different forms, but generally problems result from the interdependence between levels. Local actions or policies can be beneficial at the local level while leading to big problems on the aggregated level. Likewise, short-term solutions can aggregate into long-term problems. In the case of climate change, the interaction between ongoing local $\mathrm{CO}_{2}$ emissions and long-term climate change was ignored for a long time. Cross-level interaction can also take the form of contagion (as with fire or disease outbreaks), where small-scale problems can turn into large-scale disasters. On the institutional scale, vertical interplay has been identified as leading to important cross-level issues, such as conflicts between global institutions pertaining to the harvesting of marine mammals or tropical timber and local institutions that govern these resources at the community level (Young 2002, 2006). 


\section{Dominant responses}

Proposed responses to cross-scale issues generally involve attempts at aligning the different scales: where there is a scale mismatch, ways are sought to enhance the fit between scales (Young 2002, Olsson et al. 2007). Where mismatches occur between social and ecological scales, adaptive governance generally favors remodeling the social scale, e.g., by changing existing institutions or creating new ones so that a better fit is obtained. However, remodeling the biogeophysical scale to better fit the social scale is also an option, as when large infrastructural works such as dikes, dams, or water transfers remodel the water system to better fit societal needs at different levels of social organization. In the case of mismatch between the knowledge and decision-making scale, the levels of analysis of the generated knowledge may be scrutinized and rearranged to better fit decisionmaking needs at the different levels. Because an important challenge lies in matching a multilevel governance system with ecosystems characterized by complex interactions in time and space, the solution is seldom found at one particular scale level but requires matching multiple levels of one scale with multiple levels of another.

Responses to cross-level issues generally involve attempts at creating better links between levels (Brondizio et al. 2009). On the knowledge scale, for example, different levels of analysis can be combined into multilevel analyses in order to prevent surprises resulting from the aggregation of lower level phenomena. On the institutional scale, a key concern is linking different institutional levels such that vertical interplay is enhanced. Berkes (2006) mentions a diversity of institutional forms for dealing with cross-level issues: co-management, epistemic communities, policy networks, boundary organizations, polycentric systems, and institutional interplay. He calls these institutional forms crosslevel institutions. In any case, it appears that the opposite poles of top-down approaches (which are too blunt and insensitive to local constraints and opportunities) and bottom-up approaches (which are too insensitive to the contribution of local actions to larger problems) are inadequate for dealing with complex cross-level issues.

Because adaptive governance revolves around adapting to changing circumstances, the ability to create the right links, at the right time, around the right issues becomes crucial (Olsson et al. 2007).
To be able to mobilize and link the necessary actors and knowledge quickly and effectively across different levels, the use of bridging organizations is suggested, as well as network leadership (Olsson et al. 2006), and the creation of conditions for selforganization through enabling legislation and policies. Self-organized local responses can foster active adaptation, especially in crisis situations. These responses will often require some redundancy in the system, e.g., in the form of polycentric institutional arrangements, with nested quasiautonomous decision-making units operating at multiple levels (Folke et al. 2005, Hahn et al. 2006).

\section{COMPARISON AND OPPORTUNITIES FOR RESEARCH THEMES}

Table 1 compares the three modes of governing on a number of aspects. Although at first sight the approaches share many insights and concerns, they differ in underlying scale assumptions, and even conflict in problem definitions. Monocentric governance focuses on scales in the sense of size and scope. Levels on the jurisdictional and spatial scale are central in multilevel governance, and adaptive governance deals with spatial, temporal, institutional, and other scales, each of which includes different levels. The three different governing approaches also present a lot of starting points to improve governing strategies and governance systems. Where the monocentric governance approach opts for an ideal scale and rejects "obscure" forms of (regional) cooperation, multilevel governance does not put faith in structural changes. It takes the complicated multilevel structure as given and looks for formal and informal arrangements to handle scale interdependencies effectively. Adaptive governance uses the most differentiated scale concepts. It takes the challenge of enhancing the capacity to create the right cross-scale and cross-level links at the right time, around the right issues.

Of course all three approaches are faced with pitfalls and dilemmas, resulting in emerging research themes. Some of these themes and related dilemmas cross the different approaches. A comparison could sharpen the underlying dilemmas and research challenges. We reveal four boundary themes, in which the different approaches can complement each other. 
Table 1. Comparing scale approaches in governance theories.

\begin{tabular}{|c|c|c|c|}
\hline & Monocentric governance & Multilevel governance & Adaptive governance \\
\hline $\begin{array}{l}\text { Governing } \\
\text { paradigm }\end{array}$ & $\begin{array}{l}\text { Central authority steering } \\
\text { society }\end{array}$ & $\begin{array}{l}\text { Interactions between public and } \\
\text { private actors, from local to } \\
\text { global level }\end{array}$ & $\begin{array}{l}\text { Complex interplay of social and } \\
\text { ecological systems }\end{array}$ \\
\hline Scale definitions & $\begin{array}{l}\text { Focus on levels at the } \\
\text { jurisdictional scale, especially } \\
\text { size (number of inhabitants) and } \\
\text { territorial scope of government } \\
\text { units }\end{array}$ & $\begin{array}{l}\text { Focus on multiple levels at the } \\
\text { jurisdictional and spatial scale }\end{array}$ & $\begin{array}{l}\text { Focus on spatial, temporal, } \\
\text { institutional, knowledge, and other } \\
\text { scales, each including different } \\
\text { levels }\end{array}$ \\
\hline $\begin{array}{l}\text { Why do scales } \\
\text { matter? }\end{array}$ & $\begin{array}{l}\text { The ideal scale can provide both } \\
\text { governance capacity and } \\
\text { citizens' trust }\end{array}$ & $\begin{array}{l}\text { Governance must operate at } \\
\text { multiple levels in order to } \\
\text { capture variations in the } \\
\text { territorial reach of policy } \\
\text { externalities }\end{array}$ & $\begin{array}{l}\text { Complex interactions across scales } \\
\text { and levels are important drivers in } \\
\text { social-ecological systems }\end{array}$ \\
\hline $\begin{array}{l}\text { Problem } \\
\text { definitions }\end{array}$ & $\begin{array}{l}\text { Inappropriate size of } \\
\text { governments, regional gap, } \\
\text { overlapping jurisdictions }\end{array}$ & $\begin{array}{l}\text { Inefficiency, coordination costs, } \\
\text { and lack of democratic } \\
\text { legitimacy }\end{array}$ & $\begin{array}{l}\text { Scale mismatches and unaddressed } \\
\text { interdependencies between levels }\end{array}$ \\
\hline $\begin{array}{l}\text { Dominant } \\
\text { responses }\end{array}$ & $\begin{array}{l}\text { Structural reforms } \\
\text { (amalgamation, new authorities) } \\
\text { and clarification of } \\
\text { responsibilities }\end{array}$ & $\begin{array}{l}\text { Designing and implementing } \\
\text { coordination procedures and } \\
\text { multilevel policy arrangements }\end{array}$ & $\begin{array}{l}\text { Enhancing the fit between relevant } \\
\text { scales and creating better linkages } \\
\text { between levels }\end{array}$ \\
\hline
\end{tabular}

\section{In-depth understanding of complex processes}

An important challenge arises when actors try to put into practice the devices mentioned in the different governance approaches to horizontal modes of governance. We cannot expect that the proposed change of the governance system, like structural reforms, clarification of responsibilities, new coordination procedures, or better linkages between levels among others, occur overnight. They all involve complex processes of change that are often strongly linked with political issues (e.g., Lebel et al. 2005). All three approaches stress the need for more in-depth understanding of complex processes in relation to the preferred responses to scale-related problems. This fits into change management theory, which reveals the process of change as the most significant factor explaining the success or failure of reforms (Boonstra 2004). Because the emphasis differs, the approaches can complement each other. Monocentric governance research moves away from a focus on structures only. Researchers try to better understand the process of structural reforms, and especially dealing with differences within the newly merged organizations or formal arrangements (McKay 2004).

In the context of multilevel governance, one tries to better analyze the process of connecting betweenlevel interdependencies apart from the within-level interdependencies. Even in the case of successful collaborative governance at each of two different levels, the relation between both scale levels can still be problematic, e.g., conflicts between useful collaborative initiatives at the local level, and European Union regulation as a useful inter-state agreement.

Uncertainties due to complex nonlinear behavior of social-ecological systems have received considerable research attention in adaptive governance, but a challenge lies in addressing other kinds of uncertainties that are relevant to implementation processes of adaptive management, including scalerelated uncertainties that originate in the behavior of individuals, organizations, and societies, and uncertainties that result from the strategic behavior of actors in policy games at different levels (e.g., 
Koppenjan and Klijn 2004). Studying complex process can profit from deliberately taking into account management and network scales (Cash et al. 2006).

\section{Normative framework to deal with scales}

Amidst this complexity, normative principles that allow for evaluating and judging the governance of multiscale problems need to be developed. When monocentric governance emphasizes effectiveness, the norm of resilience dominates adaptive governance. Legitimacy is important in all three. When we integrate these principles, the governance of complex sustainability issues should be legitimate, effective, and resilient. Operationalizing these norms is far from easy. Andersson and Ostrom (2008: 74) argue that "systems that generate adequate information at multiple scales and provide legitimate decision-making procedures without being too complicated for the different actors involved have a better chance of succeeding in the challenges to govern common-pool resources than simple, streamlined systems at any one scale". It is also for this purpose that the development of a variety of overlapping jurisdictions is being encouraged as a means of generating redundancy. The question however is when do fragmented systems and overlapping jurisdictions become so complicated that they threaten legitimacy or effectiveness? This thinking in terms of variety challenges monocentric governance approaches that focus on clarity and efficiency. It also goes against the currently dominant performance oriented "new public management" (Pollitt and Bouckaert 2004). Possibly, the level of variety across scales has an optimum. The norm of adaptivity and maintaining resilience raises fundamental questions about change and continuity, especially in the face of panarchy (Gunderson and Holling 2002). Can a system be so resilient as to transform into a new system, and how can the collapse of a governance system that has just been replaced by another one be evaluated? The normative assessment of the desirability of change in one direction or another will probably have to be part of the answers to these questions.

\section{Designing policy arrangements}

All approaches require knowledge to improve governance systems by designing innovative policy arrangements. In this respect, multilevel and adaptive governance have many similarities. To develop arrangements that can accelerate multilevel processes and/or improve adaptive capacity, lessons can be learned from network management, multiparty collaboration, meta-governance, or partnerships research (Gray 1989, Kickert et al. 1997, Huxham and Vangen 2000, Fischer 2003, Hajer and Wagenaar 2003, van Bueren et al. 2003, Diamond and Liddle 2005, Feldman and Khademian 2007). These concepts share the ability to deal with changes in social, political, and ecological contexts by making flexible multiactor, multilevel, and multisectoral coordination possible, as well as by combining diverse sources of knowledge to cope with uncertainty and change. As Cash et al. (2006) put forwards, these new arrangements not only have specific jurisdictional characteristics but they also have to deal with the hierarchies of constitutions and laws (institutional scale), the levels of engagement (network scale), and the linkages between general and specific knowledge (knowledge scale).

\section{Framing of scales}

In spite of all this, little attention is paid to the way actors define scales or to the kind of "scale frames" they use to make sense of multiscale issues. It makes a difference whether, for example, climate adaptation gets framed as a local issue (and thus a local responsibility) or as a global issue (and thus a global responsibility). In human and political geography, scales are defined as social constructs, suggesting that "scale is not pre-given but a way of framing conceptions of political-spatiality" (Delaney and Leitner 1997, Marston 2000, Brenner 2001, Kurtz 2003: 894). A variety of authors have paid attention to the "politics of scale" as well (Lebel et al. 2005, Gupta 2008). This metaphor emphasizes that framing policy problems as local, regional, national, international, or transboundary, or as a short-term or long-term problem, involves strategic upscaling and downscaling and can be considered a political act. Hence, this framing is not without consequences, and it influences the interdependencies between actors, including the distribution of resources and power relations (Dewulf et al. 2006). Actors can behave strategically by scaling the 
problem such that they can either claim or reject responsibility in a situation, can get access to decision-making processes, or can obtain resources (Lebel et al. 2005). Therefore, the framing perspective can provide interesting additions to the different governing perspectives discussed above. Additionally, we presume that actors not only frame problems at a level they can control but that they also lean towards a preferred type of scale. For instance, the new generation of boundary workers might focus primarily on knowledge scales and meanwhile risk ignoring jurisdictional or constitutional scales.

\section{DISCUSSION AND CONCLUSION}

Although scale is not a new subject for governance theorists, its importance has grown over the last years. Advanced knowledge of the governance of cross-scale and cross-level dynamics is considered to be essential for coping with sustainability issues in the context of a globalizing world. However, the different ways the concept of scale is used in the social sciences is a source of confusion in collaboration with the natural sciences.

In this paper, we tried to reduce the existing conceptual confusion regarding scales by disentangling three representative approaches that address both governance and scaling. Next to adaptive governance, whose definitions and concepts seem to be more familiar for natural scientists, we analyzed monocentric governance and multilevel governance. By systematically analyzing the differences in (1) underlying views on governing, (2) assumptions about scales, (3) dominant problem definitions regarding scales, and (4) preferred responses for dealing with multiple scales, we provided conceptual clarification.

The overview presented above confirms that the way scales are defined, studied, and dealt with varies substantially across these different governance approaches. This overview allows researchers to locate their work vis-à-vis others and explore the distinctions and connections among the different approaches. With these attempts, we hope to contribute to bridging the social and natural sciences.

This paper indicates that the three approaches share some common dilemmas and blind spots. It revealed four boundary research themes, in which the different approaches can complement each other: (1) developing more in-depth understanding of complex processes and governance systems in relation to scales, (2) developing norms that allow for evaluating and judging of governance, (3) developing more knowledge to improve governance systems by designing innovative arrangements, and 4) developing insights into the politics of framing scales. Above all, the study of these themes can profit from including more scales, as proposed by Cash et al. (2006). To understand complex processes, the management and network scales should receive more attention. The institutional, network, and knowledge scales can provide additional insights into developing policy arrangements.

In the end, there is the question of judging the three approaches. Following Cash et al. (2006), who argue that there is no single, correct, or best characterization of the scale and level challenge that applies to the system as a whole, we state that there is no best governance approach either. What is more, governing societal problems as complex as the sustainability questions mentioned before is unlikely to be successful if only one approach is used (Dewulf et al. 2009). Therefore, we plead for scale-sensitive governance that rests on the multiplicity of theories. The basic argument is that multiple theories (the ones we discussed here, and others) will continue to be needed simultaneously for dealing with complex societal sustainability issues. Only variety beats variety, also at the level of governance approaches.

This raises the question if and under which conditions these different approaches to scales can exist alongside each other. As our examples show, these different modes of governance and their approaches to scales are all brought into practice. Simultaneously, we can observe the merging of municipalities, the development of multilevel arrangements, and the emergence of adaptive networks and a broad array of experiments and measures to improve the adaptive capacity of socialecological systems. In general, we can state that when some faction of the governance system wants to act on the basis of past wisdom, and some other faction wants to innovate, both factions are partially correct. This variety allows the governance system to retain both flexibility and stability (Weick 1979: 244). However, a prerequisite is that these factions keep reflecting on their own thinking and acting, and that they interact with other factions despite 
their mutual tensions. With the conceptual clarification developed in this paper, we hope to contribute to reflective dialogues among both practitioners and scholars. In the end, a variety of scale-sensitive governing approaches is needed to cope with complex sustainability issues.

Responses to this article can be read online at: http://www.ecologyandsociety.org/voll5/iss4/art29/ responses/

\section{Acknowledgments:}

This paper was written in the context of the IP/OP "Scaling and Governance" Research Program, which has been spearheaded by Wageningen University and Research Center (Wageningen UR), as part of its mission to contribute to solutions for the most pressing global environmental problems.

\section{LITERATURE CITED}

Andersen, H. 2008. The emerging Danish government reform-centralised decentralisation. Urban Research \& Practice 1:3-17.

Andersson, K. P., and E. Ostrom. 2008. Analyzing decentralized resource regimes from a polycentric perspective. Policy Science 41:71-93.

Berkes, F. 2006. From community-based resource management to complex systems: the scale issue and marine commons. Ecology and Society 11 (1):45. [online] URL: http://www.ecologyandsociety. org/vol11/iss 1/art45/.

Berkes, F., and C. Folke. 1998. Linking social and ecological systems for resilience and sustainability. Pages 1-25 in F. Berkes and C. Folke, editors. Linking social and ecological systems: management practices and social mechanisms for building resilience. Cambridge University Press, New York, USA.

Biermann, F. 2007. 'Earth system governance' as a crosscutting theme of global change research. Global Environmental Change 17:326-337.
Bish, R. L. 2001. Local government amalgamations: discredited nineteenth century ideals alive in the twenty-first. CD Howe Institute, Toronto, Ontario, Canada.

Blatter, J. 2003. Beyond hierarchies and networks: institutional logics and change in transboundary spaces. Governance 16:503-526.

Boonstra, J. J., editor. 2004. Dynamics of organizational change and learning. John Wiley \& Sons Ltd., West Sussex, UK.

Boyne, G. A. 1995. Population-size and economies of scale in local government. Policy and Politics 3:213-222.

Brenner, N. 2001. The limits to scale? Methodological reflections on scalar structuration. Progress in Human Geography 25:591.

Brondizio, E. S., E. Ostrom, and O. R. Young. 2009. Connectivity and the governance of multilevel social-ecological systems: the role of social capital. Annual Review of Environment and Resources 34:253-278.

Cash, D. W., W. N. Adger, F. Berkes, P. Garden, L. Lebel, P. Olsson, L. Pritchard, and O. Young. 2006. Scale and cross-scale dynamics: governance and information in a multilevel world. Ecology and Society 11(2):8. [online] URL: http://www.ecology andsociety.org/vol11/iss2/art8/.

Cumming, G. S., D. H. M. Cumming, and C. L. Redman. 2006. Scale mismatches in socialecological systems: causes, consequences, and solutions. Ecology and Society 11(1):14. [online] URL: http://www.ecologyandsociety.org/vol11/iss1/ art14/.

Dahl, R. A., and E. R. Tufte. 1973. Size and democracy. Stanford University Press, Stanford, California, USA.

Delaney, D., and H. Leitner. 1997. The political construction of scale. Political Geography 16:9397.

Denters, B. 2002. Size and political trust: evidence from Denmark, the Netherlands, Norway, and the United Kingdom. Environment and Planning $C$ : Government and Policy 20:793-812. 
Dewulf, A., M. Mancero, G. Cárdenas, and D. Sucozhañay. 2006. Hoe actoren complexe situaties kaderen en herkaderen: een gevalstudie het beheer van het Paute-rivierbekken [How actors frame and reframe complex situations: a case study of the management of the Paute River catchment]. In J. Hovelynck, S. de Weerdt, and A. Dewulf, editors. Relationeel organiseren. Samen leren en werken in en tussen organisaties [Relational organizing. Learning and working together, in and between organizations]. Lannoo Campus, Leuven, Belgium.

Dewulf, A. R. P. J., C. J. A. M. Termeer, R. A. Werkman, G. E. Breeman, and K. J. Poppe. 2009. Transition management for sustainability. Towards a multiple theory approach. In K. J. Poppe, C. J. A. M. Termeer, and M. A. Slingerland, editors. Transitions towards sustainable agriculture and food chains in peri-urban area's. Academic Publishers, Wageningen, Netherlands.

Diamond, J., and J. Liddle. 2005 Management of regeneration: choices, challenges and dilemmas. Routledge, London, UK.

Dietz, T., E. Ostrom, and P. C. Stern. 2003. The struggle to govern the commons. Science 302:19071912 .

Dollery, B., J. Byrnes, and L. Crasse. 2007. Economies of scale and population size in Australian local government structural reform. Centre for Local Government, School of Economics, University of New England, Armidale, New South Wales, Australia.

Duit, A., and V. Galaz. 2008. Governance and complexity: emerging issues for governance theory. Governance: An International Journal of Policy, Administration, and Institutions 21:311-335.

Edelenbos, J. 2005. Institutional implications of interactive governance: insights from Dutch practices. Governance: An International Journal of Policy, Administration, and Institutions 18:111134.

Feldman, M. S., and A. M. Khademian. 2007. The role of the public manager in inclusion: creating communities of participation. Governance: An International Journal of Policy, Administration, and Institutions 20:305-324.
Fischer, F. 2003. Reframing public policy: discursive politics and deliberative practices. Oxford University Press, Oxford, UK.

Folke, C., T. Hahn, P. Olsson, and J. Norberg. 2005. Adaptive governance of social-ecological systems. Annual Review of Environment and Resources 30:441-473.

Folke, C., L. Pritchard Jr., F. Berkes, J. Colding, and U. Svedin. 2007. The problem of fit between ecosystems and institutions: ten years later. Ecology and Society 12(1):30. [online] URL: http://www.ec ologyandsociety.org/vol12/iss1/art30/.

Gibson, C. C., E. Ostrom, and T. K. Ahn. 2000. The concept of scale and the human dimensions of global change: a survey. Ecological Economics 32:217-239.

Goldsmith, M., and L. Rose. 2002. Size and democracy. Environment and Planning $C$ : Government and Policy 20:791-792.

Gray, B. 1989. Collaborating. Finding common ground for multiparty problems. Jossey-Bass, San Francisco, California, USA.

Gunderson, L. 1999. Resilience, flexibility and adaptive management - antidotes for spurious certitude? Conservation Ecology 3(1):7. [online] URL: http://www.consecol.org/vol3/iss1/art7/.

Gunderson, L. H., and C. S. Holling. 2002. Panarchy: understanding transformations in human and natural systems. Island Press, Washington, D.C., USA.

Gupta, J. 2008. Global change: analyzing scale and scaling in environmental governance. Pages 225258 in O. Young, L. A. King, and H. Schroeder, editors. Institutions and environmental change: principal findings, applications, and research frontiers. MIT Press, Cambridge, Massachusetts, USA.

Hahn, T., P. Olsson, C. Folke, and K. Johansson. 2006. Trust-building, knowledge generation and organizational innovations: the role of a bridging organization for adaptive comanagement of a wetland landscape around Kristianstad, Sweden. Human Ecology 34:573-592. 
Hajer, M., and H. Wagenaar, editors. 2003. Deliberative policy analysis: understanding governance in the Network Society. Cambridge University Press, Cambridge, UK.

Hill, C. J., and L. E. Lynn. 2004. Is hierarchical governance in decline? Evidence from empirical research. Journal of Public Administration Research and Theory 15:173-195.

Holling, C. 1978. Adaptive environmental assessment and management. Wiley, London, UK.

Hooghe, L., and G. Marks. 2003. Unraveling the Central State, but how? Types of multilevel governance. The American Political Science Review 97:233-243.

Huitema, D., E. Mostert, W. Egas, S. Moellenkamp, C. Pahl-Wostl, and R. Yalcin. 2009. Adaptive water governance: assessing the institutional prescriptions of adaptive (co-) management from a governance perspective and defining a research agenda. Ecology and Society 14 (1):26. [online] URL: http://www.ecologyandsociety. org/vol14/iss 1/art26/.

Huxham, C., and S. Vangen. 2000. Leadership in the shaping and implementation of collaboration agendas. Academy of Management Journal 43:1159-1175.

Jordan, A. 2001. The European Union: an evolving system of multilevel governance...or government? Policy \& Politics 29:193-208.

Kickert, W. J. M., E. H. Klijn, and J. F. M. Koppenjan. 1997. Managing complex networks: strategies for the public sector. Sage, London, UK.

Kjaer, A. M. 2004. Governance. Polity Press, Malden, Massachusetts, USA.

Kooiman, J. 1993. Modern governance: new government-society interactions. Sage, London, UK.

Kooiman, J. 2003. Governing as governance. Sage, London, UK.

Koppenjan, J., and E. H. Klijn. 2004. Managing uncertainties in networks: a network approach to problem solving and decision making. Routledge, London, UK.
Kraaykamp, G., M. Van Dam, and T. Toonen. 2001. Institutional change and political participation: the effect of municipal amalgamation on local electoral turnout in the Netherlands. Acta Politica 36:402-418.

Kurtz, H. E. 2003. Scale frames and counter-scale frames: constructing the problem of environmental injustice. Political Geography 22:887-916.

Larsen, C.A. 2002. Municipal size and democracy: a critical analysis of the argument of proximity based on the case of Denmark. Scandinavian Political Studies 25:317-332.

Lebel, L., P. Garden, and M. Imamura. 2005. The politics of scale, position, and place in the governance of water resources in the Mekong region. Ecology and Society 10(2):18. [online] URL: http://www.ecologyandsociety.org/vol10/iss2/ $\underline{\operatorname{art18}}$.

Loughlin, R. J., and B. G. Peters. 1997. State traditions, administrative reform and regionalization. Pages 41-62 in M. Keating and R. J. Loughlin, editors. The political economy of regionalism. Cass, London, UK.

Marks, G. 1993. Structural policy and multilevel governance in the EC. Pages 391-411 in A. Cafruny and G. Rosenthal, editors. The state of the European community. Lynne Rienner, Boulder, Colorado, UK.

Marks, G., and L. Hooghe. 2004. Contrasting visions of multi-level governance. Pages 15-30 in I. Bache and M. Flinders, editors. Multi-level governance. Oxford University Press, Oxford, UK.

Marston, S. A. 2000. The social construction of scale. Progress in Human Geography 24:219-242.

McKay, R. B. 2004. Reforming municipal services after amalgamation: the challenge of efficiency. International Journal of Public Sector Management 17:24-47.

Olsson, P., C. Folke, V. Galaz, T. Hahn, and L. Schultz. 2007. Enhancing the fit through adaptive co-management: creating and maintaining bridging functions for matching scales in the Kristianstads Vattenrike Biosphere Reserve, Sweden. Ecology and Society 12(1):28. [online] URL: http://www.ec ologyandsociety.org/vol12/iss1/art28/. 
Olsson, P., L. H. Gunderson, S. R. Carpenter, P. Ryan, L. Lebel, C. Folke, and C. S. Holling. 2006. Shooting the rapids: navigating transitions to adaptive governance of social-ecological systems. Ecology and Society 11(1):18. [online] URL: http:/ /www.ecologyandsociety.org/vol11/iss1/art18/.

Ostrom, E. 1990. Governing the commons: the evolution of institutions for collective action. Cambridge University Press, Cambridge, UK.

Ostrom, E., M. A. Janssen, and J. M. Anderies. 2007. Going beyond panaceas. Proceedings of the National Academy of Sciences of the United States of America 104:15176-15178.

Ostrom, V., C. Tiebout, and R. Warren. 1961. The organization of government in metropolitan areas: a theoretical inquiry. The American Political Science Review:831-842.

Pahl-Wostl, C., M. Craps, A. R. P. J. Dewulf, E. Mostert, D. Tabara, and T. Taillieu. 2007. Social learning and water resources management. Ecology and Society 12:5. [online] URL: http://www.ecolog yandsociety.org/vol12/iss2/art5/.

Pierre, J., editor. 2000. Debating governance. Oxford University Press, Oxford, UK.

Pierre, J., and B. G. Peters. 2000. Governance, politics, and the state. Macmillan Press, Basingstoke, UK.

Pollitt, C., and G. Bouckaert. 2004. Public management reform: a comparative analysis. Second edition. Oxford University Press, Oxford, UK.

Rhodes, R. A. W. 1997. Understanding governance: policy networks, governance, reflexivity and accountability. Open University Press, Milton Keynes, UK.

Schaap, L. 2005. Reform and democracy in the Rotterdam region: an evaluation of the attempt to create a regional government. Pages 133-151 in $\mathrm{H}$. Heinelt and D. Kübler, editors. Metropolitan governance: capacity, democracy and the dynamics of place. Routledge, London, UK.

Scharpf, F. 1997. Games real actors play. Actorcentered institutionalism in policy research. Westview Press, Boulder, Colorado, USA.
Sørensen, E., and J. Torfing. 2005. Network governance and post-liberal democracy. Administrative Theory \& Praxis 27:197-237.

Staley, S. 1992. Bigger is not better: the virtues of decentralized local government. The Cato Institute, Washington, D.C., USA.

Ten Heuvelhof, E., H. De Bruijn, M. De Wal, M. Kort, M. Van Vliet, M. Noordink, and B. Böhm. 2007. Procesevaluatie totstandkoming PKB Ruimte voor de Rivier. Berenschot, Netherlands.

van Bueren, E. M., E. H. Klijn, and J. F. M. Koppenjan. 2003. Dealing with wicked problems in networks: analyzing an environmental debate from a network perspective. Journal of Public Administration Research and Theory 13:193-212.

Van Kersbergen, K., and F. Van Waarden. 2004. 'Governance' as a bridge between disciplines: cross-disciplinary inspiration regarding shifts in governance and problems of governability, accountability and legitimacy. European Journal of Political Research 43:143-171.

Van Tatenhove, J. 2003. Multi level governance and the 'institutional void': the interplay between front stage and backstage politics.in ECPR Conference, University of Edinburgh, Scotland, UK.

Weick, K. E. 1979. The social psychology of organizing. Random House, New York, USA.

Young, O. 2002. The institutional dimensions of environmental change: fit, interplay, and scale. MIT Press, Cambridge, Massachusetts, USA.

Young, O. 2006. Vertical interplay among scaledependent environmental and resource regimes. Ecology and Society 11(1):27. [online] URL: http:/ /www.ecologyandsociety.org/vol11/iss 1/art27/.

Young, O. R., L. A. King, and H. Schroeder, editors. 2008. Institutions and environmental change: principal findings, applications, and research frontiers. MIT Press, Cambridge, Massachusetts, USA. 